\title{
Notes on two Asian species of the spider family Deinopidae (Aranei)
}

\section{Заметки о двух азиатских видах пауков семейства Deinopidae (Aranei)}

\author{
Yejie Lin ${ }^{1}$, Peter Jäger ${ }^{2}$, Kirill G. Mikhailov ${ }^{3 *}$, Haifeng Chen ${ }^{1^{*}}$

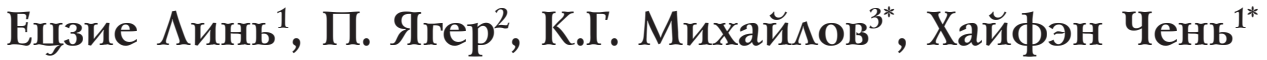

\footnotetext{
${ }^{1}$ Hebei Key Laboratory of Animal Diversity, College of Life Science, Langfang Normal University, Langfang 065000, China. E-mail: chenhaifeng@1fnu.edu.cn

${ }^{2}$ Senckenberg Research Institute, Mertonstraße 17-21, 60325 Frankfurt a. M., Germany.

${ }_{3}^{3}$ Zoological Museum MGU, Bolshaya Nikitskaya Str. 2, Moscow 125009 Russia. E-mail: mikhailov2000@gmail.com

3 Зоологический музей МГУ, ул. Большая Никитская, 2, Москва 125009 Россия.

* Corresponding authors.
}

KEY WORDS: Araneae, nomen dubium, new combination, Southeast Asia.

КЛЮЧЕВЫЕ СЛОВА: Araneae, nomen dubium, новая комбинация, Юго-Восточная Азия.

ABSTRACT. The taxonomic status of two Asian species of the spider family Deinopidae is discussed. Asianopis aruensis (Roewer, 1938) comb. n. is transferred from Deinopis MacLeay, 1839. Deinopis gubatmakiling Barrion-Dupo et Barrion, 2018 is treated as a nomen dubium. Additionally, the placement of five other species of Southeast Asian Deinopis in Asianopis Lin et $\mathrm{Li}, 2020$ is proposed.

How to cite this article: Lin Y., Jäger P., Mikhailov K.G., Chen H. 2020. Notes on two Asian species of the spider family Deinopidae (Aranei) // Arthropoda Selecta. Vol.29. No.4. P.467-469. doi: 10.15298/arthsel. 29.4.08

РЕЗЮМЕ. Обсуждается таксономический статус двух азиатских видов пауков семейства Deinopidae. Asianopis aruensis (Roewer, 1938) comb.n. перенесен из рода Deinopis MacLeay, 1839. Deinopis gubatmakiling Barrion-Dupo et Barrion, 2018 рассматривается как nomen dubium. По-видимому, остальные пять видов рода Deinopis, описанные из Юго-Восточной Азии, также принадлежат к роду Asianopis Lin et Li, 2020.

\section{Introduction}

Deinopidae is a small family with three genera and 67 extant species from tropical regions of the world, including two genera and 13 species from Asia [Li, 2020]. Currently, the genus Asianopis Lin et Li, 2020 includes eight species, and Deinopis MacLeay 1839 includes eight species from South and Southeast Asia [WSC, 2020]. It is possible that all Asian Deinopis species belong to Asianopis, but currently this cannot be confirmed because the original descriptions of these Asian Deinopis are very poor. Also, the type material of Asian Deinopis species, besides D. aruensis Roew- er, 1938 are not available in European museums. One Indian species, Asianopis goalparaensis (Tikader et Malhotra, 1978) has recently been redescribed [Basumatary et al., 2020]. The aim of this paper is to redescribe the type material of $D$. aruensis. $D$. gubatmakiling Barrion-Dupo et Barrion, 2018 is treated as a nomen dubium.

\section{Material and methods}

Specimens were preserved in $70 \%$ ethanol and examined and illustrated with a Leica MZ16 stereomicroscope with a camera lucida attachment.

Collections: RBINS - Royal Belgian Institute for Natural Sciences, Brussels, Belgium; SMF - Senckenberg Museum, Frankfurt am Main, Germany; UPLB - Museum of Natural History, Los Baños, Laguna, Philippines.

\section{Taxonomic survey}

Genus Asianopis Lin et Li, 2020

Lin et Li in Lin et al., 2020: 70.

TYPE SPECIES. Asianopis zhuanghaoyuni Lin et Li, 2020, from Fujian, China.

COMMENTS. This recently described genus differs from Deinopis, the only other genus occurring in Asia, by: the presence of a prominent setal fringe; the embolic tip with an apophysis or folded apically; the median apophysis distal lobe small and with a basal lobe; the female chelicerae with many denticles between the promarginal and retromarginal teeth or without denticles; the epigynal median plate lateral margins anchor shaped and the spermathecal duct narrow throughout its length.

DISTRIBUTION. Southeast Asia (China, Vietnam, Indonesia, India, 9 species, including one given herein). Asianopis celebensis (Merian, 1911) and A. dumogae (Merian, 1911) described from Sulawesi by the male and the female, respectively, are possibly conspecific. 
A

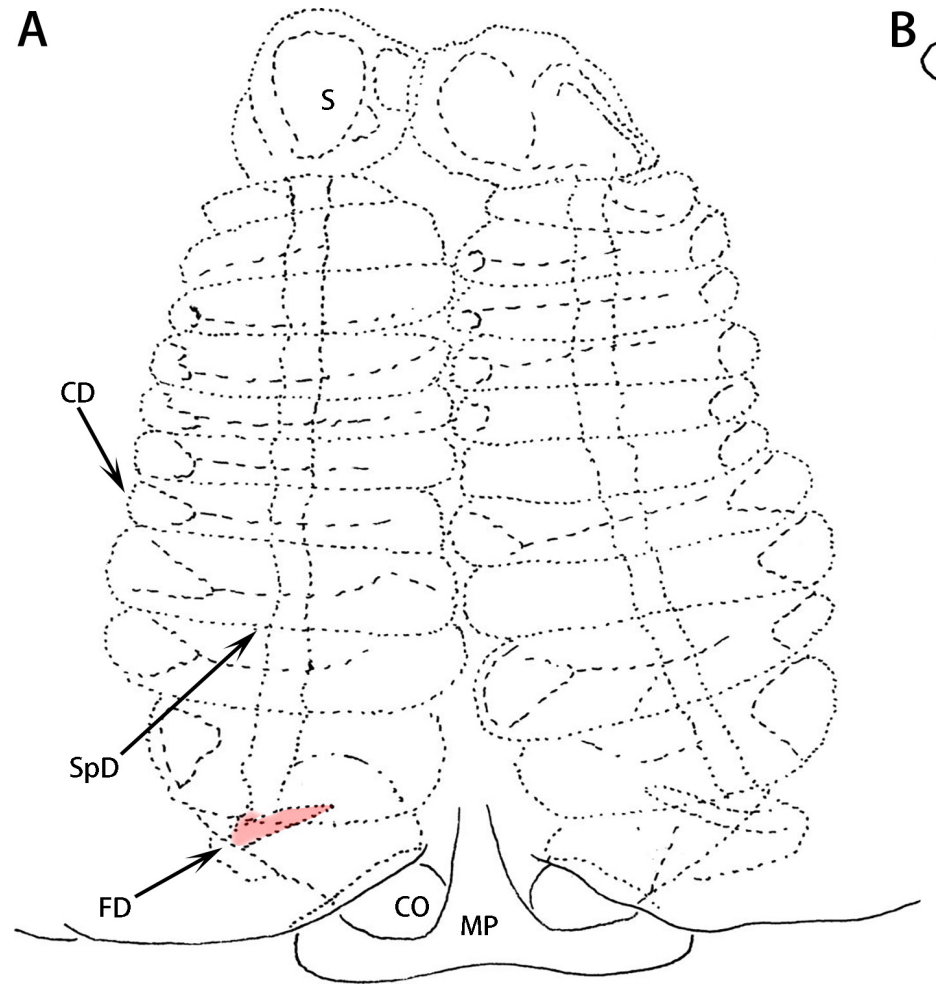

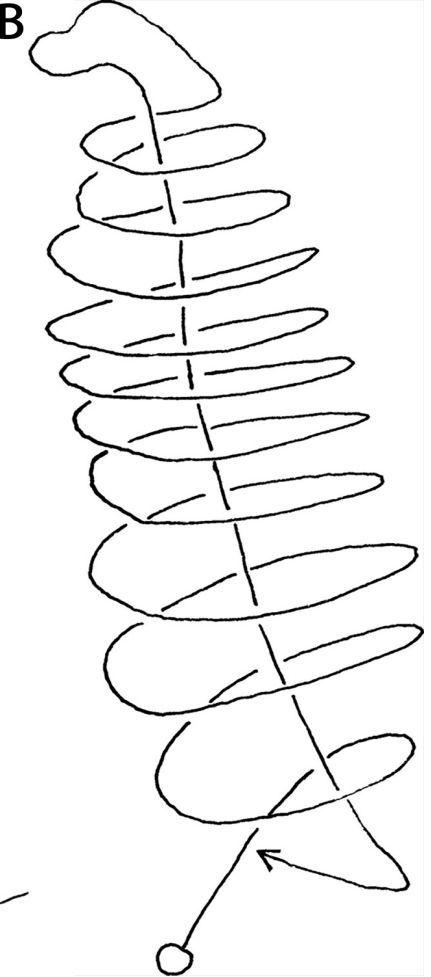

Fig. 1. Asianopis aruensis (Roewer, 1938), holotype ${ }_{+}$: A - epigyne, ventral; B — schematic course of internal duct system, ventral. Abbreviations: $\mathrm{CD}$ - copulatory duct, $\mathrm{CO}$ - copulatory opening, FD - fertilization duct, $\mathrm{MP}$ - median plate, $\mathrm{S}$ - spermatheca, SpD — spermathecal duct.

Рис. 1. Asianopis aruensis (Roewer, 1938), голотип ㅇ: А - эпигина, вентрально; В - внутренняя система каналов, вентрально, схематично. Сокращения: CD — копуляторный канал, CO — копуляторное отверстие, FD — оплодотворительный канал, МP — срединная пластинка, S - сперматека, SpD - канал сперматеки.

\section{Asianopis aruensis (Roewer, 1938) comb.n.}

Fig. 1A, B.

Deinopis aruensis Roewer 1938: 29, figs 18, 19 ().

TYPE MATERIAL EXAMINED. Holotype $q$ from Indonesia, Maluku, Aru Islands, Soengai Manoembaai [ca. 601'37.08"S $134^{\circ} 18^{\prime} 52.40^{\prime \prime} \mathrm{E}, 15 \mathrm{~m}$ ], 26.3.1929 leg. (RBINS: female; SMF 13716: epigyne, microscope slide; SMF 13717: leg III distal metatarsus, tarsus, leg IV distal tibia, metatarsus, tarsus, microscope slide).

DIAGNOSIS. The female has characters present in both the liukuensis-group and the zhuanghaoyuni-group: epigyne with an anchor-shaped median plate, with distinct copulatory openings, and a copulatory duct with 10 coils (Fig. 1A) Other Asianopis spp. have different combinations of characters: Either the copulatory duct has 3 coils, the epigyne has an anchor-shaped median plate, and the copulatory openings are distinct (liukuensis-group) or the copulatory duct has 10 coils, the epigyne has a well-developed triangular median plate, and the copulatory openings are obscured (zhuanghaoyuni-group).

DESCRIPTION. See Roewer [1938]. For an illustration of the epigyne see Figure 1.

DISTRIBUTION. Indonesia (Aru Islands).

COMMENTS. A diagnostic character of Asianopis is having the spermathecal duct narrow throughout its length, as found in this species, supporting its placement in Asianopis. However, which species group that this species belongs to is ambiguous given that it has diagnostic characters from both species groups. The epigyne has an anchor-shaped median plate, the copulatory opening is distinct and easily visible in ventral view, diagnostic characters for the liukuensis-group. The copulatory duct has 10 coils, which is characteristic for the zhuanghaoyuni-group. We place this species in the genus Asianopis Lin et Li, 2020, without suggesting an affiliation to one of the known species groups.

Genus Deinopis MacLeay, 1839

TYPE SPECIES. Deinopis lamia MacLeay, 1839, from Cuba.

COMMENTS. Currently the genus includes 46 species occurring in all continents. Species of Deinopis from the region with adequate descriptions were transferred to Asianopis [Lin et al., 2020]. It is likely that all eight species from Southeast and South Asia belong to Asianopis.

\section{Deinopis gubatmakiling Barrion-Dupo et Barrion, 2018, nomen dubium}

Deinopis gubatmakiling Barrion-Dupo, Barrion, 2018: 5, figs $1 \mathrm{~A}-\mathrm{G}, 2 \mathrm{~A}-\mathrm{E}, 3$.

TYPE MATERIAL. Holotype subadult male from Philippines, Luzon Island, Laguna Province, Los Baños, Mount Makiling forest reserve, Molawin Creek, secondary forest, at night, A.T. Barrion leg. 2-3.04.2013 (UPLB ARA-00636); 4 subadult female paratypes with same data as holotype (UPLB ARA-00637-40). Not examined. 
NOTES. The description of this species [Barrion-Dupo, Barrion, 2018] was based on immatures only. The characters provided are not sufficient for species identification.

Acknowledgements. Christoph Hörweg (Natural History Museum Vienna, Austria) and Peter van Helsdingen (Naturalis Museum in Leiden, the Netherlands) searched for the type material of Asian Deinopis in European depository institutions. English of the final draft was kindly checked and corrected by Sarah Crews (San Francisco, USA). Work of K.G. Mikhailov is supported by Moscow State University Project No. AAAA-A16-116021660077-3.

Compliance with ethical standards

Conflict of Interest: The authors declare that they have no conflict of interest.

Ethical approval: No ethical issues were raised during our research.

\section{References}

Barrion-Dupo A.L.A., Barrion A.T. 2018. Discovery of the family Deinopidae from the Philippines, with descriptions of three new species of Deinopis Macleay, 1839 // Philippine Entomologist. Vol.31 (for 2017). No.1. P.1-23.

Basumatary P., Caleb J.T.D., Das S., Brahma D. 2020. Redescription of the net-casting spider Asianopis goalparaensis (Tikader et Malhotra, 1978) comb.n. (Araneae: Deinopidae) from India // Arthropoda Selecta. Vol.29. No.3. P.325-329.

Doleschall L. 1859. Tweede Bijdrage tot de kennis der Arachniden van den Indischen Archipel // Acta Societatis Scientiarum Indica-Neerlandica. Bd.5. S.1-60.

Li S. 2020. Spider taxonomy for an advanced China // Zoological Systematics. Vol.45. No.2. P.73-77.

Lin Y., Shao L., Hänggi A., Caleb J.T.D., Koh J.K.H., Jäger P., Li S. 2020. Asianopis gen. nov., a new genus of the spider family Deinopidae from Asia // ZooKeys Vol.911. P.67-99.

Roewer C.F. 1938. Araneae // Résultats scientifiques du Voyage aux indes orientales néerlandaises de la SS. AA. RR. le Prince et la Princesse Leopold de Belgique. Mémoires du Musée Royal d'Histoire Naturelle de Belgique. T.3. Fasc.19. P.1-94.

WSC. 2020. World Spider Catalog, version 21.0. Natural History Museum, Bern. http://wsc.nmbe.ch [accessed 28 November 2020]

Responsible editor Yu.M. Marusik 